\title{
KONTRIBUSI KONSEP DIRI DAN SOFT SKILL TERHADAP KREATIVITAS MAHASISWA JURUSAN S1 PENDIDIKAN BIOLOGI IKIP PGRI BALI
}

\author{
Dewa Gede Eka Sastra Wiguna ${ }^{1}$, I Nengah Sukawidana ${ }^{2}$ \\ Universitas PGRI Mahadewa Indonesia ${ }^{1,2}$ \\ Email: sastrawigunapsi@gmail.com,nengahsukawidana23@gmail.com
}

\begin{abstract}
ABSTRAK
Penelitian ini bertujuan untuk mengetahui: (1) kontribusi konsep diri terhadap kreativitas mahasiswa jurusan S1 Pendidikan Biologi, (2) kontribusi soft skill terhadap kreativitas mahasiswa jurusan S1 Pendidikan Biologi, dan (3) kontribusi konsep diri dan soft skill terhadap kreativitas mahasiswa jurusan S1 Pendidikan Biologi. Penelitian ini merupakan penelitian korelasional. Penelitian ini dilakukan di Jurusan S1 Pendidikan Biologi IKIP PGRI BALI. Sampel dalam penelitian ini sebanyak 75 orang, pengambilan sampel dilakukan dengan menggunakan teknik strata random sampling. Metode pengumpulan data berupa kuesioner dengan menggunakan skala Likert. Metode analisis data yang digunakan adalah regresi ganda. Hasil penelitian menunjukkan bahwa (1) konsep diri berkontribusi terhadap kreativitas mahasiswa Jurusan S1 Pendidikan Biologi IKIP PGRI BALI $(r=0,77 ; p<0,05$ dan $t=16 ; 11 p<0,05)$. (2) soft skill berkontribusi terhadap kreativitas mahasiswa Jurusan S1 Pendidikan Biologi IKIP PGRI BALI ( $\mathrm{r}=0,60 ; \mathrm{p}<$ $0,05$ dan $t=8,00 ; p<0,05)$ ). (3) konsep diri dan soft skill berkontribusi terhadap kreativitas mahasiswa Jurusan S1 Pendidikan Biologi IKIP PGRI BALI ( $r=0,76 ; p<0,05$ dan F = 48,49; $p$ $<0,05)$ serta memiliki sumbangan efektif sebesar $58 \%$.
\end{abstract}

Kata kunci: konsep diri, soft skill, kreativitas

\begin{abstract}
This study aims to determine: (1) contribution the self concept of creativity undergraduate students education of biology Departement, (2) contribution the soft skill of creativity undergraduate students education of biology Departement, and (3) contribution the self concept and soft skill of creativity undergraduate students education of biology Departement.This study is a correlational study. The research was conducted at undergraduate degree education of biology Departement IKIP PGRI BALI. The sample in this study as many as 75 people, sampling is done using strata random sampling technique. Methods of data collection in the form of questionnaires using a Likert scale. Methods of data analysis used was multiple regression.The results showed that (1) the self concept contribute of creativity undergraduate students education of biology Departement $(r=0.77, p<0.05$ and $t=16,11, p<0.05)$. (2) the soft skill contributes of creativity undergraduate students education of biology Departement $(r=0.60, p<0.05$ and $t=8.00, p$ $<0.05)$ ). (3) self concept and soft skill contributes of creativity undergraduate students education of biology Departement ( $r=0.76, p<0.05$ and $F=48,49, p<0.05)$ as well as having effective contribution by $58 \%$.
\end{abstract}

Key words: self concept, soft skill, creativity 


\section{PENDAHULUAN}

Pendidikan diharapkan dapat meningkatkan kualitas kehidupan pribadi maupun masyarakat, serta mampu menghasilkan sumber daya manusia yang berkualitas dan profesional. Faktanya kualitas pendidikan di Indonesia saat ini masih memprihatinkan. Ini dibuktikan dengan kualitas indeks pengembangan manusia Indonesia yang masih rendah.. Menilik Indeks Pengembangan Manusia (Human Development Index) yaitu komposisi dari peringkat pencapaian pendidikan, kesehatan, dan penghasilan per kepala menunjukkan bahwa indeks pengembangan manusia Indonesia masih rendah. Diantara 176 negara di dunia, Indonesia menempati urutan ke-102 pada tahun 1996, ke-99 tahun 1997, ke-105 tahun 1998, ke-109 tahun 1999 dan menurun 112 pada tahun 2000, dan pada tahun 2018 menempati urutan 111 dari 189 negara (UNDP, n.d.)

Persoalan urgent sekarang adanya ketertinggalan di dalam mutu pendidikan dan solusi apa yang diperlukan untuk meningkatkan kualitas pendidikan di Indonesia. Baik pendidikan formal maupun informal. Pendidikan memang telah menjadi penopang dalam meningkatkan sumber daya manusia Indonesia untuk pembangunan bangsa. Oleh karena itu, kita seharusnya dapat meningkatkan sumber daya manusia Indonesia yang tidak kalah bersaing dengan sumber daya manusia di negara-negara lain.

Dalam dunia pendidikan kita mengenal adanya proses belajar dan pembelajaran. Belajar dan pembelajaran merupakan konsep yang saling berkaitan, belajar merupakan proses perubahan tingkah laku akibat adanya interaksi dengan lingkungannya. Pembelajaran merupakan seperangkat tindakan yang dirancang untuk mendukung proses belajar peserta didik dengan memperhitungkan kejadian kejadian eksternal yang berperan terhadap kejadian internal yang berlangsung di dalam peserta didik (Sanjaya, 2008). Tidak dapat dipungkiri bahwa setiap siswa memiliki kemampuan berbeda yang dapat dikelompokkan menjadi siswa berkemampuan tinggi, sedang dan rendah. Setiap kemampuan siswa ditunjukkan oleh motivasi, soft skill, konsep diri. kesiapan, disiplin dll, sehingga tercapai hasil belajar yang maksimal.

Proses pendidikan merupakan perubahan pengetahuan (kognitif), keterampilan (psikomotor) dan sikap (afektif) seseorang, maka pendidikan seharusnya menghasilkan output dengan kemampuan yang proporsional antara hard skill dan soft skill. Selain karena kurikulum yang memiliki muatan soft skill yang rendah dibanding muatan hard skill, ketidakseimbangan antara soft skill dengan hard skill juga dapat disebabkan oleh proses pembelajaran yang menekankan pada perolehan nilai hasil ulangan maupun nilai hasil ujian. Banyak guru yang memiliki persepsi bahwa peserta didik yang memiliki kompetensi yang baik adalah memiliki nilai hasil ulangan/ujian yang tinggi. Persepsi ini menyebabkan guru terbelenggu dalam proses pembelajaran yang konvensional (teacher centered), baik dalam penyampaian demikian juga pada proses penilaiannya. Saat ini sudah saatnya guru lebih kreatif dan inovatif dalam menciptakan proses belajar mengajar yang berpusat pada siswa (student centered learning). Setiap orang termasuk peserta didik sudah memiliki soft kill walaupun berbeda-beda. Soft skill ini dapat dikembangkan menjadi lebih baik atau bernilai (diterapkan dalam kehidupan seharihari) melalui proses pembelajaran.

Konsep diri sangat besar peranannya bagi mahasiswa, yaitu konsep diri mahasiswa mempengaruhi perilaku belajar dan prestasi belajar mahasiswa. Sebab pada hakikatnya semakin tinggi konsep diri seseorang maka akan semakin mudah ia mencapai keberhasilan. Dengan konsep diri yang tinggi seseorang akan bersikap optimis, berani mencoba hal-hal baru, berani mengambil resiko, penuh percaya diri, antusias, merasa dirinya berharga, dan berani 
menetapkan tujuan hidup. Sebaliknya, semakin rendah konsep diri mahasiswa, maka semakin sulit seseorang untuk berhasil karena konsep diri yang rendah akan mengakibatkan tumbuh rasa tidak percaya diri, takut gagal sehingga tidak berani mencoba hal-hal baru dan menantang, merasa diri bodoh, rendah diri, merasa tidak berguna, pesimis, serta bebagai perasaan dan perilaku inferior lainnya (Suardana, 2010).

Konsep diri sebagai pandangan yang dimiliki setiap orang mengenai dirinya sendiri yang terbentuk, baik melalui pengalaman atau pengamatan terhadap diri sendiri, baik konsep diri secara umum maupun konsep diri secara spesifik termasuk konsep diri dalam kaitannya dalam bidang akademik, karier, atlentik, kemampuan artistik dan fisik. Konsep diri merupakan verifikasi diri, konsisten diri dan kompleksitas diri yang terbuka untuk interprestasi sehingga secara umum berkaitan dengan pembelajaran dan menjadi mediasi variabel motivasi dan pilihan tugastugas pembelajaran, Black \& Bornholt (2000) dalam syamsul Bachri Thalib (2010).

Selain konsep diri, keberhasilan seorang peserta didik dalam menyelesaikan tugas-tugas dan kewajibannya ditentukan pula oleh kreativitas seorang mahasiswa tersebut, dalam hal ini kreativitas seseorang akan sangat menentukan kesuksesannya dalam hasil belajar seorang mahasiswa. Kreativitas anak sangat penting dipupuk dan dikembangkan, karena: Pertama, dengan berkreasi anak dapat mewujudkan dirinya, dan perwujudan diri termasuk salah satu kebutuhan pokok dalam hidup manusia. Seorang ahli, Maslow (Munandar, 2002) yang menyelidiki kebutuhan manusia menekankan bahwa kreativitas merupakan manifestasi diri individu yang berfungsi yang berfungsi sepenuhnya dalam perwujudan dirinya. Orang yang sehat mental, yang bebas dari hambatanhambatan, dapat mewujudkan diri sepenuhnya. Hal ini berarti ia berhasil mengambangkan dan menggunakan semua bakat dan kemampuannya dan dengan demikian memperkaya hidupnya. Kedua, kreativitas atau berpikir kreatif, sebagai kemampuan untuk melihat bermacammacam kemungkinan penyelesaian terhadap suatu masalah, merupakan bentuk pemikiran yang sampai saat ini masih kurang mendapat perhatian dalam pendidikan formal. Di sekolah terutama dilatih adalah pengetahuan, ingatan, dan kemampuan berpikir logis, atau penalaran, yaitu kemampuan menemukan satu jawaban yang paling tepat terhadap masalah yang diberikan berdasarkan informasi yang tersedia. Ketiga, bersibuk diri secara kreatif tidak hanya bermanfaat, tetapi juga memberikan kepuasan kepada individu. Keempat, kreativitaslah yang memungkinkan manusia meningkatkan kualitas hidupnya. Dalam era pembangunan ini tak dapat dipungkiri bahwa kesejahteraan dan kejayaan masyarakat dan negara kita tergantung pada sumbangan kreatif, berupa ide-ide baru, penemuan-penemuan baru, dan teknologi baru dari anggota masyarakatnya. Untuk mencapai hal itu, sikap dan perilaku kreatif perlu dipupuk sejak dini, agar anak didik kelak tidak hanya menjadi konsumen pengetahuan, tetapi mampu menghasilkan penemuan baru, tidak hanya mencari pekerjaan, tetapi mampu menciptakan pekerjaan baru (Utami Munandar, 1992: 46).

Dari uraian di atas, terlihat adanya perbedaan konsep diri dan soft skill yang dimiliki mahasiswa diduga akan memberikan dampak yang berbeda terhadap hasil belajar biologi mahasiswa. Namun, seberapa jauh kontribusi konsep diri dan soft skill yang dimiliki terhadap hasil belajar biologi mahasiswa khususnya mahasiswa S1 pendidikan biologi IKIP PGRI Bali. Untuk itu, dilakukan suatu penelitian untuk mengetahui Kontribusi Konsep diri dan Soft skill Terhadap kreatifitas Pada Mahasiswa S1 Pendidikan Biologi.

\section{METODE}

Penelitian ini merupakan penelitian korelasional. Dalam penelitian ini dicari kontribusi antara variabel konsep diri dan 
variabel Soft skill terhadap variabel kreativitas.

Populasi penelitian adalah seluruh mahasiswa semester I-V Jurusan S1 Pendidikan Biologi IKIP PGRI Bali. Populasi dibagi menjadi tiga stratum, yaitu semester I, III dan V. dari masing-masing stratum kemudian diambil sampel secara strata random sampling sebanyak 25 orang dari masing-masing stratum.

Dalam penelitian ini terdapat tiga variabel, yaitu variable kreativitas sebagai variabel terikat (dependent), sedangkan variable konsep diri dan soft skill sebagai variabel bebas (independent).

Data konsep diri dikumpulkan dengan menggunakan metode kuesioner yang berisikan skala konsep diri. Dimensi konsep diri terdiri dari kendali, asal-usul, pengakuan, jangkauan dan daya tahan. Data variabel soft Skill dikumpulkan dengan kuesioner yang berisikan skala skala Soft Skill. Dimensi Soft Skill terdiri dari komitmen, tanggung jawab, kerjasama, kreatifitas dan etika. Data Kreativitas dikumpulkan dengan kuesioner yang berisikan skala kreativitas. Dimensi kreativitas terdiri dari kelancaran, keluwesan, keaslian, elaborasi..

.Hasil penelitian dianalisis secara bertahap. Tahapan-tahapan tersebut adalah uji prasyarat dan uji hipotesis. Uji prasyarat yang dilakukan adalah uji normalitas data, uji autokorelasi dengan menggunakan uji Durbin-Watson, Uji multikolinieritas menggunakan Variance Inflation Factor (VIF), Uji heteroskedastisitas dan uji linieritas dengan menggunakan analisis tabel Anova berbantuan SPSS 17.00 for windows.

Jika uji prasyarat sudah terpenuhi maka dapat dilanjutkan dengan uji hipotesis. Untuk uji hipotesis pertama dan kedua diuji dengan menggunakan korelasi Product Moment, dan Uji hipotesis ketiga menggunakan regresi ganda.

\section{HASIL DAN PEMBAHASAN}

Hasil uji hipotesis pertama yaitu kontribusi konsep diri terhadap kreativitas mahasiswa S1 Pendidikan Biologi menunjukkan perolehan $r_{\text {hitung }}$ sebesar 0,77 . Kemudian nilai $r_{\text {tabel }}$ pada taraf signifikansi $5 \%$ dengan sampel $(\mathrm{N}=75)$ sebesar 0,138 . Dengan demikian $r_{\text {hitung }}(0,77)>r_{\text {tabel }}(0,138)$. Ini berarti, $\mathrm{H}_{0}$ yang menyatakan bahwa tidak terdapat kontribusi konsep diri terhadap kreativitas mahasiswa jurusan S1 Pendidikan Biologi ditolak. Sebaliknya, Ha yang menyatakan bahwa terdapat kontribusi konsep diri terhadap kreativitas mahasiswa jurusan S1 Pendidikan Biologi diterima. Hasil perhitungan signifikansinya melalui uji-t untuk korelasi parsialnya menunjukkan bahwa $t_{\text {hitung }}$ sebesar 16,11 . Nilai $t_{\text {tabel }}$ pada taraf signifikansi $5 \%$ dengan derajat kebebasan (n-2) sebesar 1,96. Dengan demikian, $16,11>1,96$ atau $t_{\text {hitung }}>t_{\text {tabel }}$. Ini berarti, $\mathrm{H}_{0}$ yang menyatakan bahwa tidak terdapat Kontribusi konsep diri secara parsial terhadap Kreativitas mahasiswa jurusan S1 Pendidikan Biologi ditolak. Sebaliknya, Ha yang menyatakan bahwa terdapat Kontribusi konsep diri secara parsial terhadap kreativitas mahasiswa S1 Pendidikan Biologi diterima. Hasil perhitungan uji-r untuk korelasi parsialnya menunjukkan bahwa $r_{\text {hitung }}$ sebesar 0,77 . Kemudian nilai $r_{\text {tabel }}$ pada taraf signifikansi 5\% dengan sampel $(\mathrm{N}=75)$ sebesar 0,138 . Dengan demikian $r_{\text {hitung }}(0,77)>r_{\text {tabel }}(0,138)$. Hasil perhitungan signifikansinya melalui uji-t untuk korelasi parsialnya menunjukkan bahwa $t_{\text {hitung }}$ sebesar 16,11 . Nilai $t_{\text {tabel }}$ pada taraf signifikansi $5 \%$ dengan derajat kebebasan (n-2) sebesar 1,96. Dengan demikian, $16,11>1,96$ atau $t_{\text {hitung }}>t_{\text {tabel }}$. Ini berarti, $\mathrm{H}_{0}$ yang menyatakan bahwa tidak terdapat Kontribusi konsep diri secara parsial terhadap kreativitas mahasiswa jurusan S1 Pendidikan Biologi ditolak. Sebaliknya, Ha yang menyatakan bahwa terdapat Kontribusi Konsep diri secara parsial terhadap kreativitas mahasiswa jurusan S1 Pendidikan Biologi diterima. Dengan demikian dapat disimpulkan bahwa terdapat Kontribusi Konsep diri yang 
signifikan terhadap kreativitas mahasiswa jurusan S1 Pendidikan Biologi dan Konsep diri memberikan Kontribusi secara parsial terhadap kreativitas mahasiswa S1 Pendidikan Biologi pada taraf signifikansi 5\%. Dari hasil perhitungan juga diperoleh sumbangan relatif dan sumbangan efektif dinyatakan bahwa sumbangan relatif konsep diri sebesar $92 \%$ dan sumbangan efektifnya sebesar 53\%.

Secara prinsip konsep diri mampu memberikan kontribusi terhadap kreativitas. Jika dikaji Konsep diri dirumuskan sebagai skema kognitif atau pandangan dan penilaian tentang diri sendiri, yang mencakup atributatribut spesifik yang terdiri atas komponen pengetahuan dan komponen evaluatif. Komponen pengetahuan termasuk sifat-sifat karakteristik fisik, sedangkan komponen evaluatif termasuk peran, nilai-nilai, kepercayaan diri, harga diri dan evaluasi diri global, Campbell at al., 1966 (dalam Syamsul B. T, 2010). Konsep diri terbentuk dari interaksi dari individu dengan lingkungannya secara terus menerus mulai sejak lahir. Semenjak masa kanak-kanak, seseorang telah belajar berpikir dan merasakan dirinya ditentukan oleh orang lain dan lingkungannya, seperti orang tua, dosen, teman-teman, atau orang lain disekitarnya (Louisajanda, 1978). Pada hakikatnya semakin tinggi konsep diri seseorang maka akan semakin mudah ia mencapai keberhasilan. Dengan konsep diri yang tinggi seseorang akan bersikap optimis, berani mencoba hal-hal baru, berani mengambil resiko, penuh percaya diri, antusias, merasa dirinya berharga, dan berani menetapkan tujuan hidup. Sebaliknya, semakin rendah konsep diri mahasiswa, maka semakin sulit seseorang untuk berhasil karena konsep diri yang rendah akan mengakibatkan tumbuh rasa tidak percaya diri, takut gagal sehingga tidak berani mencoba hal-hal baru dan menantang, merasa diri bodoh, rendah diri, merasa tidak berguna, pesimis, serta bebagai perasaan dan perilaku inferior lainnya (Brooks, W.D, Emmert, 1976). Konsep diri yang positif akan memberikan dampak baik terhadap kreativitas, begitu pula sebaliknya konsep diri negatif akan memberikan hasil yang kurang terhadap kreativitas mahasiswa. Hal ini sesuai dengan hasil penelitian yang telah dilakukan oleh (Qondias, 2012), (Maulana, 2012) dan Suardana, (2010) yang menyatakan bahwa konsep diri berpengaruh terhadap prestasi belajar siswa. Begitu pula hasil penelitian oleh (Masna, 2011) yang menyatakan ada kontribusi positif konsep diri terhadap keprofesionalan guru.

Hasil uji hipotesis kedua yaitu kontribusi soft skill terhadap kreativitas mahasiswa S1 Pendidikan Biologi menunjukkan perolehan $r_{\text {hitung }}$ sebesar 0,60 dan nilai $r_{\text {tabel }}$ pada taraf signifikansi $5 \%$ dengan sampel $(\mathrm{N}=75)$ sebesar 0,138 . Dengan demikian diperoleh $r_{\text {hitung }}(0,60)>$ $\mathrm{r}_{\text {tabel }}(0,138)$. Ini berarti, $\mathrm{H}_{0}$ yang menyatakan bahwa tidak terdapat Kontribusi soft skill terhadap kreativitas mahasiswa jurusan S1 Pendidikan Biologi ditolak. Sebaliknya, Ha yang menyatakan bahwa terdapat Kontribusi soft skill terhadap kreativitas mahasiswa jurusan S1 Pendidikan Biologi diterima. Hasil perhitungan uji-t untuk korelasi sederhananya menunjukkan bahwa $t_{\text {hitung }}$ sebesar 8,00. Nilai tabel pada taraf signifikansi $5 \%$ dengan derajat kebebasan (n-2) sebesar 1,96. Dengan demikian, 8,00 > 1,96 atau $t_{\text {hitung }}>\mathrm{t}_{\text {tabel }}$. Ini berarti, $\mathrm{H}_{0}$ yang menyatakan bahwa tidak terdapat Kontribusi soft skill secara signifikan terhadap kreativitas mahasiswa S1 Pendidikan Biologi ditolak. Sebaliknya, Ha yang menyatakan bahwa terdapat Kontribusi soft skill secara signifikan terhadap kreativitas mahasiswa S1 Pendidikan Biologi diterima.

Hasil perhitungan uji-r untuk korelasi parsialnya menunjukkan bahwa $r_{\text {hitung sebesar } 0,60 \text {. Kemudian nilai } r_{\text {tabel }} \text { pada }}$ taraf signifikansi 5\% dengan sampel $(\mathrm{N}=$ 75) sebesar 0,138. Dengan demikian $r_{\text {hitung }}$ $(0,60)>r_{\text {tabel }}(0,138)$. Hasil perhitungan uji-t untuk korelasi parsialnya menunjukkan bahwa thitung sebesar 8,00 . Nilai $t_{\text {tabel }}$ pada taraf signifikansi 5\% dengan derajat kebebasan (n-2) sebesar 1,96. Dengan 
demikian, soft skill tidak berpengaruh secara parsial terhadap kreativitas mahasiswa S1 Pendidikan Biologi ditolak. Sebaliknya, Ha yang menyatakan bahwa soft skill memberikan Kontribusi secara parsial terhadap kreativitas mahasiswa jurusan S1 Pendidikan Biologi diterima. Dengan demikian dapat disimpulkan bahwa terdapat Kontribusi soft skill terhadap kreativitas mahasiswa S1 Pendidikan Biologi. soft skill memiliki Kontribusi secara parsial terhadap kreativitas mahasiswa S1 Pendidikan Biologi pada taraf signifikansi 5\%. Dari hasil perhitungan sumbangan relatif dan sumbangan efektif dinyatakan bahwa sumbangan relatif soft skill sebesar $8 \%$ dan sumbangan efektif soft skill sebesar 5\%.

Widyatmika (2010) mengungkapkan bahwa soft skill adalah ketrampilan seseorang dalam berhubungan dengan orang lain (termasuk dengan dirinya sendiri). Atribut soft skill, dengan demikian meliputi nilai yang dianut, motivasi, perilaku, kebiasaan, karakter dan sikap. Atribut soft skill ini dimiliki oleh setiap orang dengan kadar yang berbeda-beda, dipengaruhi oleh kebiasaan berfikir, berkata, bertindak dan bersikap. Namun, atribut ini dapat berubah jika yang bersangkutan mau merubahnya dengan cara berlatih membiasakan diri dengan hal-hal yang baru.

Untuk menghadapi persaingan ke depan menjadi orang pintar saja belum cukup, dibutuhkan orang yang mampu berpikir kreatif. Kemampuan berpikir kreatif dapat ditingkatkan salah satunya dengan cara meningkatkan kemampuan soft skill. Dengan kemampuan soft skill ini siswa akan memiliki keterampilan berkomunikasi yang efektif, inovasi dan kreativitas, berpikir analitis, fleksibilitas, kesiapan untuk berubah, memiliki sikap dan nilai-nilai yg benar, ketrampilan negosiasi, ketrampilan persuasif, ketrampilan mengatur waktu, kemampuan memecahkan masalah, kemampuan beradaptasi, kemampuan memimpin dan membangun tim. Dengan memiliki keterampilan-keterampilan tersebut dapat meningkatkan kemampuan berpikir kreatif mahasiswa. Mengingat pentingnya soft skill dalam upaya meningkatkan kemampuan berpikir kreatif siswa, setiap siswa diharapkan untuk memiliki kemampuan soft skill.

Hasil uji hipotesis ketiga yaitu kontribusi konsep diri dan soft skill terhadap kreativitas mahasiswa S1 Pendidikan Biologi menunjukkan perolehan $\mathrm{r}_{\text {hitung }}$ sebesar 0,76 dan $r_{\text {tabel }}$ sebesar 0,13. Dengan demikian 0,76 $>0,13$ atau $r_{\text {hitung }}>r_{\text {tabel. }}$ Ini berarti, $\mathrm{H}_{0}$ yang menyatakan bahwa tidak terdapat Kontribusi konsep diri dan soft skill terhadap Kreativitas mahasiswa S1 Pendidikan Biologi ditolak. Sebaliknya, Ha yang menyatakan bahwa Kontribusi konsep diri dan soft skill terhadap Kreativitas mahasiswa S1 Pendidikan Biologi diterima. Selanjutnya hasil perhitungan uji signifikansi dengan menggunakan uji $F$ diperoleh $F_{\text {hitung }}$ sebesar 48,49 > 3,04 atau $\mathrm{F}_{\text {hitung }}>\mathrm{F}_{\text {tabel. }}$. Ini berarti, $\mathrm{H}_{0}$ yang menyatakan bahwa Konsep diri dan soft skill secara simultan tidak berkontribusi signifikan terhadap kreativitas mahasiswa S1 Pendidikan Biologi. Sebaliknya, Ha yang menyatakan bahwa konsep diri dan soft skill secara simultan memiliki Kontribusi signifikan terhadap kreativitas mahasiswa S1 Pendidikan Biologi diterima. Dengan demikian dapat disimpulkan bahwa terdapat Kontribusi konsep diri dan soft skill terhadap Kreativitas mahasiswa S1 Pendidikan Biologi. Konsep diri dan soft skill secara simultan memiliki Kontribusi signifikan terhadap kreativitas mahasiswa S1 Pendidikan Biologi. Dari hasil perhitungan sumbangan efektif dinyatakan bahwa total sumbangan efektif konsep diri dan soft skill terhadap Kreativitas S1 Pendidikan Biologi adalah sebesar 58\%. Ini berarti bahwa konsep diri dan soft skill memiliki Kontribusi sebesar 58\% terhadap Kreativitas mahasiswa S1 Pendidikan Biologi dan sebanyak $42 \%$ diKontribusi oleh faktorfaktor lain.

Kualitas materi konsep diri dan soft skill yang dimiliki oleh setiap mahasiswa memiliki kontribusi yang sangat besar 
terhadap kreativitas mahasiswa. Secara bersama-sama konsep diri yang tinggi akan menjadikan seseorang akan bersikap optimis, berani mencoba hal-hal baru, berani mengambil resiko, penuh percaya diri, antusias, merasa dirinya berharga, dan berani menetapkan tujuan hidup. Konsep diri ini sangat besar peranannya bagi mahasiswa yang bersangkutan, sebab konsep diri ini merupakan pusat semua prilaku individu. Dengan demikian prilaku belajar dan prestasi belajar sangat dipengaruhi oleh konsep diri. Konsep diri adalah bagaimana orang berpikir tentang dirinya dan nilai apa yang diletakkan pada dirinya. Konsep diri sangat penting artinya dalam menentukan tujuan yang akan dirumuskan dalam sikap yang dipegang, tingkah laku yang diprakasai dan respon yang dilakukan terhadap orang lain dan lingkungannya (Cohen, 1976). Secara bersama-sama Untuk menghadapi persaingan ke depan menjadi orang pintar saja belum cukup, dibutuhkan orang yang mampu berpikir kreatif. Kemampuan berpikir kreatif dapat ditingkatkan salah satunya dengan cara meningkatkan kemampuan soft skill. Dengan kemampuan soft skill ini siswa akan memiliki keterampilan berkomunikasi yang efektif, inovasi dan kreativitas, berpikir analitis, fleksibilitas, kesiapan untuk berubah, memiliki sikap dan nilai-nilai yg benar, ketrampilan negosiasi, ketrampilan persuasif, ketrampilan mengatur waktu, kemampuan memecahkan masalah, kemampuan beradaptasi, kemampuan memimpin dan membangun tim. Dengan memiliki keterampilan-keterampilan tersebut dapat meningkatkan kemampuan kreativitas mahasiswa.

\section{SIMPULAN}

Pertama, Konsep diri memiliki kontribusi terhadap kreativitas mahasiswa S1 Pendidikan Biologi IKIP PGRI Bali ( $\mathrm{r}=$ 0,77; $p<0,05$ dan $t=16,11 ; p<0,05)$. Rasa Percaya Diri memiliki sumbangan relatif sebesar sebesar $92 \%$ dan dan sumbangan efektifnya sebesar 53\%.

Kedua, soft skill memiliki kontribusi terhadap kreativitas mahasiswa S1 Pendidikan Biologi IKIP PGRI Bali $(\mathrm{r}=$ $0,60 ; p<0,05$ dan $t=8,00 ; p<0,05)$. Soft skill memiliki sumbangan relatif sebesar $8 \%$ dan sumbangan efektifnya sebesar 5\%.

Ketiga, Konsep diri dan Soft skill memiliki kontribusi terhadap kreativitas mahasiswa S1 Pendidikan Biologi IKIP PGRI Bali $(r=0,76 ; p<0,05$ dan $F=48,49$; $\mathrm{p}<0,05)$. Konsep diri dan soft skill memiliki total sumbangan efektif terhadap kreativitas mahasiswa S1 Pendidikan Biologi sebesar $53 \%$.

Melihat besarnya konsep diri dan soft dalam upaya meningkatkan kreativitas mahasiswa S1 Pendidikan Biologi IKIP PGRI BALI, maka dalam kegiatan pembelajaran perlu dilakukan hal-hal sebagai berikut:

Pertama, konsep diri memberikan dampak yang signifikan terhadap kreativitas mahasiswa. Dengan mengetahui konsep diri mahasiswa, maka dosen hanya perlu menciptakan kondisi dan menyesuaikan model pembelajaran yang mampu menunjang dan mengoptimalkan penyerapan informasi oleh mahasiswa tersebut. untuk itu dalam pembelajaran di kelas dosen perlu memberikan kuesioner untuk mengetahui konsep diri mahasiswa agar mendapatkan proses pembelajaran yang optimal.

Kedua, soft skill juga memiliki dampak signifikan terhadap kreativitas mahasiswa. Dengan mengetahui soft skill mahasiswa, maka dosen dapat memberikan metode dan model pembelajaran yang sesuai agar mendapatkan proses pembelajaran yang optimal.

Selain itu melalui identifikasi konsep diri soft skill mahasiswa, maka dosen dapat menyiapkan perangkat pembelajaran yang sesuai untuk mengoptimalkan proses pembelajaran.

\section{DAFTAR PUSTAKA}


Brooks, W.D, Emmert, P. (1976). Interpersonal Community.

Cohen, L. (1976). Educational Research in Classroom and School. Harper and Row Publisher.

Louisajanda, V. (1978). Personal Adjustment The Psychology of Everyday Life. Silver Burdett Company.

Masna. (2011). Kualitas Layanan Guru Dalam Pembelajaran Ditinjau Dari Kompetensi Pedagogik, Kompetensi Profesional, Dan Konsep Diri (Studi tentang Persepi Para Guru Sekolah Dasar di Kecamatan Denpasar Timur. Pascasarjana Undiksha.

Maulana, M. R. (2012). Determinasi Konsep Diri, Ketahanmalangan Dan Motivasi Berprestasi Terhadap Hasil Belajar Ekonomi Siswa Kelas X Sma Saraswati Singaraja.

Munandar, U. (2002). Pengembangan Kreativitas Anak Berbakat. Depdikbud dan Rineka Cipta.

Qondias, D. (2012). Determinasi Ketahanmalangan dan Konsep Diri terhadap Motivasi Berprestasi dalam Kaitannya dengan Hasil Belajar IPS kelas VIII SMP N 3 Singaraja. Tesis (tidak diterbitkan). Pasca Sarjana Undiksha.

Suardana. (2010). Pengaruh Model Pembelajaran Inquiri TerbimbingTerhadap Prestasi Belajar IPA Pada Siswa Kelas VII SMP Negeri 1 Dawan Ditinjau Dari Konsep diri Siswa. Tesis (tidak diterbitkan). Pasca Sarjana Undiksha (Vol. 0). Pasca Sarjana Undiksha.

UNDP. (n.d.), paket sembako secara. 2019. http://hdr.undp.org/sites/all/themes/hdr _theme/country-notes/IDN.pdf

Widyatmika. (2010). Soft Skills Dalam Proses Pembelajaran. http://staff.unud.ac.id/ widyatmika/?p $=27$, 